\title{
The Relation between Pedagogical Approaches in Music Education and Students' Performance AnXiety
}

\section{Potrjeno / Accepted 21.05..2018 \\ Objavljeno / Published 21.6.2018}

\section{Keywords: Elly Bašić; functional music pedagogy; music education; music school with standard program; music performance anxiety}

\author{
Ključne besede: \\ Elly Bašič; \\ funkcionalna \\ glasbena pedagogika; \\ glasbena vzgoja; \\ glasbena šola s \\ standardnim \\ programom; \\ trema pri izvajanju \\ glasbe
}

UDK/UDC $781: 159.942$

\author{
BLAŽENKA BAČLIJA SUSIĆ
}

${ }^{1}$ University of Zagreb, Faculty of Teacher Education, Zagreb, Croatia

\section{CORRESPONDING AUTHOR/KORESPONDENČNI AVTOR blazenkabs@gmail.com}

\begin{abstract}
Povzetek Performance anxiety is a significant problem in general education, as well as in music education. Therefore, the purpose of this study is to determine whether the Functional Music Pedagogy (FMP) approach has a significant effect on music performance anxiety in children. The neglect of improvisation as a basic methodological tool in FMP instrumental practice could explain why the main effect of school type was not significant in this sample. The lack of Music Performance Anxiety differences between students who have learned music through distinct pedagogical approaches can be interpreted as a result of the physiological and psychological developmental changes that arise on entering puberty as a consequence of hormonal changes and increased emotions during early adolescence
\end{abstract}

\section{Razmerje med pedagoškimi pristopi v glasbeni vzgoji in učenčevo tremo pri nastopanju}

Trema pri nastopanju je pomemben problem tako v splošnem izobraževanju kot v glasbeni vzgoji. Namen te študije je ugotoviti, ali pristop funkcionalna glasbena pedagogika (FMP, angl. Functional Music Pedagogy) pomembno vpliva na tremo otrok pri izvajanju glasbe. Zanemarjanje improvizacije kot temeljnega metodičnega orodja $\mathrm{v}$ vadbi instrumentalne glasbe bi lahko pojasnilo, zakaj glavni učinek tipa šole $\mathrm{v}$ tem vzorcu ni bil pomemben. Pomanjkanje razlik v glasbeni tremi med učenci, ki so se glasbe učili po različnih glasbenopedagoških pristopih, je mogoče interpretirati kot rezultat sprememb njihovega fizičnega in psihičnega razvoja, ki nastanejo ob vstopu v puberteto kot posledica hormonskih sprememb in povečanih čustev $\mathrm{v}$ zgodnji adolescenci. 


\section{Introduction}

The contemporary lifestyle and advances in technology have contributed to the growth of uncertainty, tension and fear. According to Jeffers (2014), fear is an epidemic in modern society because people today have numerous fears, such as the fear of change, living and death. Competition and ranking are now present in every discipline, and these contribute to the development of several fears, such as the fear of criticism, of making mistake and of failure. Therefore, even thinking about public performance for most people, regardless of their sex, education, age or experience, from all disciplines and professions (musicians, actors, teachers, speakers, priests, etc.) induce a feeling of fear. Most of them would rather come down with the 'flu than perform in front of an audience, which is reasonable according to studies that associate performance anxiety with an increased possibility of "significant physical and mental health deterioration, as well as a lower possibility of success" (Rost \& Schermer, 1986, p. 127).

Even though most musicians choose their vocation because of their love for music and the desire to share it with others, they tend to experience fear and agitation on stage rather than excitement (Lehmann et al., 2007). That state of mind elevates stress, tension, fear of mistakes, and fear of failure during rehearsals and at the actual performance, all of which further perpetuates a high level of anxiety among professional musicians and students. A successful musician should, in addition to excellent technical skills and musicality, also possess the stamina to endure the psychological and physical demands associated with performing in front of an audience.

An encouraging fact is that, according to Jeffers (2014), fear is first and foremost an educational problem, not a psychological one. Therefore, education in general and music education need to align their programs with the current demands of the education system in order to encourage divergent opinions, freedom of expression, and creativity, while encouraging students to develop creative and independent problem-solving skills. Considering the numerous benefits of music for human development, music education should be available to every child, with the aim of promoting children's holistic development. In addition to sensibility, creativity, and similar abilities associated with the arts, music education should represent a method of cognition, experience, communication and freedom of expression, without feelings of fear and anxiety during music performance. Every music instructor and parent should have that goal in mind.

Several causes of public performance anxiety have been identified. The fight-orflight response was first described by Walter Cannon in 1932, and it is considered to be a primal response to stress as an important survival mechanism. Just like animals, humans respond to acute stress by fighting a certain threat or fleeing from 
it. That is an automatic and natural reaction of the human body to stressful and potentially dangerous situations. The body as an organism attempts to find a solution, so several physiological and biochemical processes allow the brain to react in a stressful situation in order to protect us from potential dangers. In order to activate that defensive mechanism for emergency situations, the brain activates the sympathetic nervous system. Hormones affect organs throughout the body in that state, so people experience several sensations: fluttering in the chest, excessive sweating, shortage of breath, dry mouth, anxiety lumps in the throat, butterflies in the stomach, blurred vision, difficulty focusing, tension, trembling, etc. (Lehmann et al., 2007). The situation itself is not stressful, but our perception makes it stressful and produces those symptoms.

Given that we are exposed to the judgment of others during a public performance, we are afraid of being ridiculed, exposed as imposters or rejected by the audience. Fear of public performance is also called stage fright, and it is considered to be one of the most common social fears (Williams, 2012). Social anxiety is associated with feelings of fear, self-consciousness, and emotional imbalance in a controlled social situation. That type of anxiety arises when people want to leave a good impression but doubt their ability to succeed (Schlenker \& Leary, 1982). Focus turns to catastrophic cognitive states that have an adverse effect on a person's concentration and performance. This is a shared trait between social anxiety and public performance anxiety, which causes a state similar to social phobia at its peak (Kenny \& Osborne, 2006).

The American Psychological Association (2000) considers performance anxiety, nervousness and shyness as normal experiences in social situations that involve strangers, so these should not be diagnosed as disorders if they do not significantly affect a person's ability to function. Children are usually exposed to social anxiety when communicating with adults. Anxiety can be triggered by a conscious, rational concern or by unconscious processes associated with previous experiences and sensory perceptions. For example, unpleasant experiences with public performance can contribute to the development of negative cognition regarding future performances (Barlow, 2002; Beck, 1995; Beck, Emery, \& Greenberg, 1985). When a person begins the performance, they start their self-assessment, which focuses mainly on their inability to face the threat.

Salmon (1990) defines Music Performance Anxiety (MPA) as an experience of consistent perception of incompetence or an actual reduction of skills in a public context to an extent that cannot be justified given the performer's existing talent and hours of practice. MPA is one of the psychological variables that most affect the quality of musical performances in front of an audience (Papageorgi, Creech and Welch, 2011) and can eventually lead to a series of cognitive, physiological and 
motor difficulties (Studer, Danusera, Hildebrandt, Arial, \& Gomez, 2011; Wilson, 2002).

Wilson (2002) identified three sources of anxiety during music performances: the person, the situation and the performance task. The musician can have a certain predisposition towards anxiety and unrealistic attitudes about performing. Situational stress can also arise given the characteristics and circumstances related to a specific performance, and it is important that the task does not exceed the performer's skills because a sense of control over the composition is important in order to perform it with confidence (Lehmann et al., 2007).

In order to explain performance anxiety, Barlow (2000) recommends an integrated triple vulnerability model that can explain why generalized anxiety or mood disorders arise. These vulnerabilities include general biological vulnerability, general psychological vulnerability, and disorder-specific psychological vulnerability. General vulnerabilities alone, such as genetic predispositions and early environmental influences, can trigger the onset of generalized anxiety disorder, but only disorder-specific vulnerabilities can cause specific anxiety disorders, such as panic disorder or phobias. Barlow defines anxiety as "a state in which a person has no control ... a state of helplessness ... because they cannot achieve the desired results and outcomes ..." That definition is similar to the definition of perfectionism suggested by Frost, Marten, Lahart, and Rosenblate (1990, p. 449). For example, "excessive concern about possible mistakes, high personal standards, high expectations from parents, the perception of criticism from parents, having second thoughts about the quality of other people's activities, and a penchant for order and organization" (Barlow, 2000, p. 1249).

Anxiety or fear of performing in public can have an early onset among musicians. According to Kenny and Osborne (2006), young children do not experience the same type of anxiety as adults because they enjoy performing and are blissfully unaware of any flaws in their performance. However, Williams (2012) notes that children can also experience fear of public performances. Children in a choir can be used as an example because they tend to perform well during rehearsals, but can become paralyzed by fear during a performance in front of an audience. Students in school also tend to display similar reactions when they need to carry out a presentation or answer a question in front of the class.

Kenny and Osborne (2006) argue that children grow out of the phase, "Mommy, look at me, aren't I smart?" and transition to a different way of thinking: "Please, don't make me perform; I know I'll make a mistake and embarrass myself' (p. 103). That transition is associated with various factors, such as innate temperament, anxiety traits, cognitive capacity growth, self-preservation, the ability to change perspectives in late childhood and adolescence, parenting, interpersonal 
experiences, perception and the interpretation of the world, technical skills, dexterity, and performance-specific experiences associated with negative or positive outcomes. Lehmann et al. (2007) also argue that children enrolled in music school often experience (MPA) because their parents pressure them into achieving results. Pruett (2003) believes that an elevated state of anxiety among musicians, combined with high expectations from parents, a low level of social support, and a high frequency of testing their abilities in a competitive environment can trigger psychological, behavioral and cognitive responses that resemble anxiety during public performances.

\section{Music Performance Anxiety in Children}

Anxiety during music performance was first discovered by accident when Simon and Martens (1979) investigated anxiety in sport by comparing anxiety associated with athletic performance to anxiety associated with test-taking and musical performances. A total of 749 boys participated in that study, and it was found that boys between the ages of 9 and 14 experience the highest level of anxiety during solo musical performances. Public performances in a band were associated with the highest level of anxiety compared to other group activities, including team sports. This study was replicated by Ryan $(1998,2004,2005)$ and showed that music students experienced anxiety regarding public performance in a manner similar to the anxiety experienced by a sportsman or sportswoman before a match.

About $90 \%$ of adult musicians begin their musical training before 12 years of age and $46 \%$ of these before the age of 7 (Nagel, 1993). Lehmann and Kristensen (2014) found that the relation between the age of onset and musical achievement is that the acquisition of certain technically demanding skills requires early initiation into music. Since a music career today begins much earlier, it is important to explore the expression of MPA in younger students. Some research suggests that MPA is present very early in children and that it can occur at the early stages of musical training, even at the age of 3 (Boucher and Ryan, 2011). Zarza-Alzugaray et al. (2018) confirmed the notion that the age when pupils start learning to play music leads to significantly different levels of MPA later on. Some authors noted that understanding MPA would be beneficial, both to those who go on to work in a highly competitive industry, and also for those performing at an amateur or semiprofessional level (Thomas and Nettelbeck, 2014).

Ryan (2003) researched anxiety symptoms during music performance on a sample of 173 children between $3 \mathrm{rd}$ and 7 th grade. It was found that most children present psychological symptoms similar to those of adult musicians and that their performance anxiety is negatively correlated with self-esteem and quality of performance. In addition, the author concluded that, regardless of their sex, 
education, age or experience, MPA increases with a larger audience and greater significance of the performance (Ryan, 2005). According to their symptoms, the children demonstrated a significantly higher state of anxiety on days when they performed in school concerts (Ryan, 1998, 2004). That study proves the existence of music performance anxiety in children and shows the characteristics it shares with performance anxiety in adults (Kenny and Osborne, 2006). Furthermore, Osborne and Kenny (2008) found that teenagers between the ages of eleven and eighteen also experience some level of performance anxiety. Based on an analysis of 16 studies, Brugués (2011) concluded a review of the literature by stating that adolescents between the ages of fourteen and nineteen have high MPA scores and show symptoms similar to those of adults. She thus concluded that children rarely experience MPA, but that it appears during the transition to adolescence.

Research examining the implications for music educators of creating effective learning environments and safe spaces for music learning reveals that $23 \%$ of children and $34 \%$ of adolescents suffer from clinically relevant levels of music performance anxiety. These percentages may vary in different contexts according to differences in teacher approaches, community values, family support, and the student's state of mental wellbeing (Hendricks, Smith and Stanuch, 2014).

Results of a study measuring performance anxiety levels of 74 teenagers attending a German special music school demonstrated that high school students do experience significant levels of performance anxiety. A third of teenagers felt that their performance was negatively affected, and a tenth felt that their career would be negatively impacted by anxiety. It is particularly important to point out that most students wished they had more help in managing their anxiety (Fehm and Schmidt, 2006).

Habe and Kržič (2017) explored MPA in music school students in early adolescence. The results reveal that there are no differences in MPA between younger (aged 10-12) and older (aged 13-15) music students in early adolescence, while MPA is more prevalent in girls than in boys. Furthermore, they concluded that students who started performing early in childhood, those who enjoyed being on stage and had positive first performance experiences, experienced less MPA.

Dempsey (2015) concluded that there are differences in the intensity of the experience of MPA between children and adolescents, while adolescents reported having intense performance anxiety symptoms as children.

Osborn and Kenny (2008) conducted research involving 298 students aged 11 to 19 , who described their worst musical performance in writing. The authors assessed the student's descriptions in six areas: situational and behavioral factors, emotional, cognitive and somatic symptoms of anxiety and performance. The results showed that girls experienced an imbalance with exercise anxiety more intensely than boys, 
and that as much as $78 \%$ of pupils had a negative initial experience with performance. The study highlighted the importance of using cognitive presentations in the identification of exercise anxiety and cognitive-behavioral therapy in the management of exercise anxiety.

\section{Pedagogical Approaches in Music Education}

The traditional approach to teaching music focuses on reproducing the knowledge and education of professional musicians, but several pedagogical approaches use music to facilitate the holistic development of children, regardless of which future professions they choose. This humanistic approach to music was introduced by several authors at the end of the 19th and beginning of the 20th century, including Orff, Dalcroz, Kodály, Willems, Suzuki, and the Croatian music teacher Elly Bašić. Their primary goals were to teach art, teach music through play and spontaneity, and support freedom of expression and creativity, while avoiding perfectionism, competitiveness and fear of making mistakes. Whereas the traditional approach in music education follows a rigid plan, the approaches proposed by these authors are student-centered, and thus focus on their needs, abilities and interests (Renzulli \& Reis, 1997; Renzulli, 1999; Sternberg, 2003).

The aforementioned goals were integrated into Functional Music Pedagogy (FMP) by Elly Bašić, and the fundamental concepts of that approach are best described by the following postulates: all children have a right to music education; all children have a good ear for music; all children have a sense of rhythm; having a good ear for music is not the same as being musical; all children have a creative imagination (Perak Lovričević, 2005). In accordance with these postulates, the FMP approach does not evaluate a student's creative work. In order to protect students from the fear of making mistakes and failing, Elly Bašić decided to remove grading, so that children did not become motivated to learn only for the sake of getting good grades. That is why music schools that implement the FMP approach do not use standard grading methods. Furthermore, the approach is based on methods and didactic principles aimed at reducing the environmental pressure that causes children to feel afraid and stressed. Nor do music schools that use the FMP approach conduct entrance exams to select students because that practice promotes individualism and is associated with a specific formal structure and workflow organization. In standard programs used by music schools, grades are the primary method for motivating students, but FMP uses grades as just one way to track the students' progress in music over time. FMP schools do not share grades with children, nor do they send grade reports to their parents, except at the end of the final year. Elly Bašić emphasized belief in children and their dispositions, as well as emotional support and nurture, as the basis for their growth without developing a fear of failure. 
Improvisation is also emphasized as the fundamental and most important method that children use to create music, as well as one of the most natural and creative methods that can be used in music education. Spontaneous improvisation is specifically valued because children can become active participants in the creative process through active discovery and learning. Children then have the opportunity to express themselves in an area that makes them feel safe (visual, literary and kinetic) and thus to combine multiple art forms.

According to the teaching plans and programs designed for FMP music schools (2006), besides children's natural predisposition for music, teachers should also encourage the development of their imagination and creativity and help them develop a holistic, well-rounded personality. Standard teaching plans and programs for music and dance schools (2006) also mention the education of professional musicians with different profiles and occupations as one of their goals. Given that goal, music schools that have adopted the standard program have a selection process during enrollment that chooses students based on their predispositions, and they use grading as the primary evaluation method for assessing students' knowledge and skills.

\section{Methods}

\section{Research problems and hypotheses}

The research problem on which this study focuses concerns the differences in somatic and cognitive features, performance contexts and performance evaluations between students enrolled at the Elly Bašić Music School, which implements the Functional Music Pedagogy (FMP) approach, and those enrolled at another music school in Zagreb using the standard music teaching program. In accordance with the research problem, the following three hypotheses were developed:

H1: The type of school and grade will have a significant effect on how students assess their somatic and cognitive features before and after a public performance.

H2: The type of school and grade will have a significant effect on how students assess their performance context during an exam or a public performance.

H3: The type of school and grade will have a significant effect on how students assess their performance evaluation during an exam or a public performance.

\section{Participants}

The sample was drawn from two music schools located in Zagreb, Croatia and consisted of 2324 th-, 5th-, and 6th-grade students, most of whom were female, $n=$ 141. The distribution of students by grade and type of school is shown in Table 1 . 
Table 1. The Distribution of Students by Grade and Type of School

\begin{tabular}{cccc}
\hline Grade & \multicolumn{2}{l}{ Type of School } & Total \\
\hline \multicolumn{1}{c}{ FMP } & \multicolumn{1}{c}{ SP } \\
\hline 4th & $36(33.34 \%)$ & $38(30.65 \%)$ & $74(31.90 \%)$ \\
\hline 5th & $31(28.70 \%)$ & $47(37.90 \%)$ & $78(33.62 \%)$ \\
\hline 6th & $41(37.96 \%)$ & $39(31.45 \%)$ & $80(34.48 \%)$ \\
\hline Total & $108(100.00 \%)$ & $124(100.00 \%)$ & $232(100.00 \%)$
\end{tabular}

Notes. FMP - Functional Music Pedagogy; SP - standard program

\section{Instrument}

The Music Performance Anxiety Inventory for Adolescents (MPAI-A; Osborne \& Kenny, 2005) was administered to the students at the end of the school year. The scale consists of 15 items divided into three subscales: Somatic and Cognitive Features, Performance Context, and Performance Evaluation. Somatic and Cognitive Features refers to the psychological manifestations of performance anxiety before and during the performance, as well as the fear of making mistakes during the performance. The Performance Context subscale lists the advantages performers associate with performances in single or group contexts and the nature of the audience. The third subscale, Performance Evaluation, contains items associated with the performer's or audience's evaluation of the performance, the consequences of those evaluations (usually when a mistake occurs) and difficulty concentrating on the performance in front of an audience. The Cronbach's alpha of 0.88 suggests that the scale has good internal consistency. Approval was obtained from the authors to translate the questionnaire from English to Croatian and use it in this study.

\section{Results}

The two-way ANOVA results are shown in Table 2. The main effects of grade and school, as well as their interaction effect, on Somatic and Cognitive Features and Performance Context were not statistically significant. Therefore, the first and third research hypotheses were rejected. The main effect of grade on Performance Evaluation was statistically significant, but the main effect of school and the interaction effect were not. Based on these results, the second hypothesis was partially confirmed because differences between the Performance Evaluation scores of students from different grades were statistically significant. 
Table 2. Two-way ANOVA Main and Interaction Effects by Subscale

\begin{tabular}{llcc}
\hline \multicolumn{1}{c}{ Subscale } & Effect & $\boldsymbol{f}$ & $\boldsymbol{p}$ \\
\hline Somatic and Cognitive Features & School & 0.06 & 0.81 \\
\hline & Grade & 2.49 & 0.08 \\
\hline & School * Grade & 2.37 & 0.10 \\
\hline Performance Evaluation & School & 0.02 & 0.90 \\
\hline & Grade & 3.70 & 0.03 \\
\hline Performance Context & School * Grade & 0.06 & 0.94 \\
\hline & School & 0.25 & 0.62 \\
\hline & Grade & 0.73 & 0.49 \\
\hline & School * Grade & 0.47 & 0.63
\end{tabular}

Differences in Performance Evaluation scores between groups by grade were analyzed using the Bonferroni method. The average Performance Evaluation score was significantly higher for 5 th-grade students compared to $4^{\text {th }}$-grade students, 3.39 \pm 1.27 vs. $2.88 \pm 1.05, \mathrm{t}=1.94, \mathrm{p}=0.027$. The average Performance Evaluation score for 6th-grade students, $3.00 \pm 1.07$ was lower than it was for 5th-grade students, but the difference between the two groups was not statistically significant, $\mathrm{t}=-1.25, \mathrm{p}=0.11$. Average scores on individual items constituting the Performance Evaluation subscale by grade are shown in Table 3. It was found that 5 th-grade students were significantly more likely to panic after making mistakes compared to 4 th-grade students, $\mathrm{t}=2.87, \mathrm{p}=0.002$. The comparisons between groups on other items found no statistically significant differences, but the scores in Table 3 show that 5th-grade students in this sample have the highest levels of performance anxiety compared to students from other grades.

Table 3. Mean Scores for Each Item on the Performance Evaluation Subscale by Grade

\begin{tabular}{llll}
\hline \multicolumn{1}{c}{ Item } & \multicolumn{3}{c}{ Grade } \\
\hline 7. When I perform in front of an audience, I find it hard to & 2.09 & 2.57 & 2.32 \\
\hline 8. If I make a mistake during a performance, I usually panic. & 2.61 & 3.72 & 3.14 \\
\hline 10. When I finish performing, I usually feel happy with my & 4.03 & 3.97 & 3.80 \\
\hline 13. I worry that my parents or teacher might not like my & 2.78 & 3.30 & 2.74 \\
\hline
\end{tabular}




\section{Discussion}

The main effect of school type, which refers to the schools' distinct methodological approaches to teaching music, was not statistically significant. As some research has revealed, levels of MPA can vary in different contexts, depending on differences in teacher approaches, community values, family support and the student's state of mental wellbeing (Hendricks, Smith and Stanuch, 2014), as well as the transition from childhood to adolescence when children have a more pronounced experience of MPA (Brugues, 2011; Dempsey, 2015). The farther along children are in the stage of puberty, the more vulnerable they are to experiencing and coping with MPA (Habe and Kržič, 2017).

The music school that adopted the FMP approach uses spontaneous improvisation only during the first stage of music education (i.e., 1st and 2 nd grade), which could explain why the main effect of school type was not significant in this sample.

Given the specifics of the FMP approach, including the use of alternative evaluation methods instead of grading, the application of spontaneity and improvisation to develop students' freedom of expression, and the specific A/B program introduced in the third stage of music education (5th and 6th grades) to adapt instruction to the students' abilities and interests, it was expected that students enrolled at the Elly Bašić Music School would report a lower level of performance anxiety compared to the students from the other school. In accordance with the assumption that children's creative work should not be evaluated, schools that implement the FMP approach do not grade their students in class, and so a lower performance anxiety score during solfeggio lessons in front of other students and teachers was expected from students enrolled in those schools. Methodological games are used to revise the content of solfeggio lessons, so that approach should reduce children's performance anxiety even further.

On the other hand, the actual implementation of improvisation to encourage spontaneity and develop freedom from fear of making mistakes and a sense of selfconfidence can be reflected in a person's performance. A survey of piano teachers found that most of them $(71 \%)$ use improvisation only during the first stage (i.e., 1 st and 2nd grades) of their students' music education. According to the participants, improvisation is rarely used because the short duration of music classes does not allow them to implement that method effectively. Therefore, assuming that those findings can be generalized to music teachers who teach other instruments, students experience improvisation only early in their music education. Using improvisation in the classroom liberates the students in a sense, since it helps them develop a sense of self-worth and self-confidence (Bačlija Sušić, 2012); it is thus possible that no significant differences between the groups from different 
schools were found because the students in this sample had not been practicing improvisation recently.

Significant differences were observed between groups in different grades on the Performance Evaluation subscale, which collects data on concentration during public performances, controlling the situation after making mistakes, and concerns regarding the opinions of parents and teachers. It was found that 5 th-grade students experienced higher performance anxiety compared to 4th-grade students, possibly because of the difference in age and experience.

Furthermore, students tend to determine their interest in music in the 5th-grade and decide whether they will continue their music education, so it is possible that those students who continue their music education in the 6th grade are less concerned about public performance.

Some specific characteristics of the FMP approach, such as the A and B program in the third phase of music education (5th and 6th grades), could also explain the increase in performance anxiety observed between the 4th and 5th grades. According to Wilson (2002), those performance tasks that do not exceed the performers' skills can reduce the severity of performance anxiety. If musicians have a sense of control over the composition they are performing, they will remain confident. As long as students choose a program that is consistent with their skills and interests, they will also be more likely to avoid public performance anxiety if they perform with interest, dedication and love.

\section{Conclusion}

The results of this study indicate that there are no significant differences between subjects from different schools in the self-assessments of their Somatic and Cognitive Features, Performance Context and Performance Evaluation scores. Experiencing MPA can be attributed to the transition from childhood to adolescence and the physiological and psychological developmental changes that arise when children enter puberty (Brugues Ortiz, 2011; Dempsey, 2015; Habe and Kržič, 2017) as a consequence of hormonal changes and increased emotions during early adolescence (Buchanan et al. 1992 in Papalia, Olds and Feldman, 2003). It can vary in different contexts according to differences in teacher approaches, community values, family support, and the student's state of mental wellbeing (Hendricks, Smith and Stanuch, 2014).

Neglecting improvisation in FMP instrumental practice (Bačlija Sušić, 2012), along with the other factors mentioned could be among the reasons for the lack of differences between the two pedagogical approaches with regard to MPA. 
Nevertheless, it is important to aim for a humanistic approach to music education in order to emphasize the development of the students' personalities rather than the evaluation of their knowledge and ability. Emphasizing spontaneity and improvisation at all stages of music education instead of evaluation and grading is recommended to reduce performance anxiety in students.

The age of puberty is a period of searching for one's identity, a time when a teenager tries to invent his own self (Erikson, 1968 in Papalia, Olds and Feldman, 2003). Therefore, to increase the students' sense of confidence, personal freedom and control over life choices, it is important to stimulate the development of their internal locus of control rather than the external locus of control, which stimulates students to find motivation from external sources, such as grades, competition results, etc. Because MPA is expressed in early childhood, primary prevention should probably begin much earlier.

A significant factor that can reduce the fear of public performance is the teachers' personality and performance in class, which has to be student-centered and focused on helping them develop a love for music. The experience of peace and love is, according to Jampolsky (2010), the best way to liberate a person from fear. Only that approach in music education can contribute to the development of free and creative individuals, without fear of public performance, who will be able to use all of their vital energies to create and control their own lives.

MPA among children and adolescents in music is not well understood and requires further research, especially since music careers today start much earlier than before. Therefore, it is important to examine the various strategies for controlling MPA in children and adolescents because research on performance anxiety in children and adolescents is still incomplete when compared to the literature on adult MPA.

\section{References}

American Psychiatric Association. (2000). Diagnostic and Statistical Manual of Mental Disorders (4th ed.). Washington, DC: American Psychiatric Association.

Bačlija Sušić, B. (2012). Akcijsko istraživanje improvizacije u individualnoj nastavi klavira. Tonovi: časopis glazbenih i plesnih pedagoga, 60(2), 25-58.

Beck, A. T. (1995). Cognitive therapy: Past, present, and future. In M. J. Mahoney (Ed.), Cognitive and Constructive Psychotherapies: Theory, research, and practice (pp. 29-40). New York, NY: Springer Publishing.

Beck, A. T., Emery, G., \& Greenberg, R. (1985). Anxiety Disorders and Phobias: A common perspective. New York, NY: Basic.

Barlow, D. (2000). Unravelling the mysteries of anxiety and its disorders from the perspective of emotion theory. American Psychologist, 55, 1247-1263.

Barlow, D. H. (2002). Anxiety and Its Disorders: The nature and treatment of anxiety and panic (2nd ed.). New York, NY: Guilford Press. 
Boucher, H., \& Ryan, C. A. (2011). Performance stress and the very young musician. Journal of Research in Music Education, 58(4), 329-345.

Brugués, A. O. (2011). Music performance anxiety-part 1. A review of its epidemiology. Medical Problems of Performing Artists, 26(2), 102-105.

Dempsey, E. (2015). Music Performance Anxiety in Children and Teenagers: Effects of Perfectionism, SelfEfficacy, and Gender. Ottawa: University of Ottawa. Available at http://goo.gl/i6hJyr

Fehm, L., \& Schmidt, K. (2006). Performance anxiety in gifted adolescent musicians. Journal of Anxiety Disorders, 20(1), 98-109.

Frost, R., Marten, P., Lahart, C., \& Rosenblate, R. (1990). The dimensions of perfectionism. Cognitive Therapy and Research, 14(5), 449-468.

Habe, K., Kržič, V. (2017). Doživljanje izvajalske anksioznosti učencev glasbene šole v zgodnjem mladostništvu. Glasbeno-pedagoški zbornike, 26, 33-39.

Hendricks, K. S., Smith, T. D. \& Stanuch, J. (2014). Creating safe spaces for music learning. Music Educators Journal, 101(1), 35-40.

Jampolsky, G. (2010). Ljubav je život ber straha. Zagreb: Naklada Veble.

Jeffers, S. J. (2014). Osjeti strah, a ipak to učini. Zagreb: Mozaik knjiga.

Kenny, D. (2011). The Psychology of Music Performance Anxiety. Oxford: Oxford University Press.

Kenny, D. T., \& Osborne, M. S. (2006). Music performance anxiety: New insights from young musicians. Advances in Cognitive Psychology, 2(2-3), 103-112.

Lehmann, A. C., Sloboda, J. A., \& Woody, R. H. (2007.). Psychology for Musicians: Understanding and acquiring the skills. New York, NY: Oxford University Press.

Lehmann, A. C. \& Kristensen, F. (2014). "Persons in the Shadow" brought to light: Parents, teachers, and mentors - how guidance works in the acquisition of musical skills. Talent Development \& Excellence, 6(1), 57-70.

Leuchtenburg, W. (1963). Franklin D. Roosevelt and the New Deal, 1932-1940. New York, NY: Harper and Row.

Maslow, A. H. (1976). The Farther Reaches of Human Nature. New York, NY: Penguin.

Nagel, J. J. (1987). An examination of commitment to careers in music: Implications for alienation from vocational choice. Dissertation Abstracts International, 42(5-A), 1154-1155.

Osborne, M. S., \& Kenny, D. T. (2005). Development and validation of a music performance anxiety inventory for gifted adolescent musicians. Journal of Anxiety Disorders, 19(7), 725-751.

Osborne, M. S., \& Kenny, D. T. (2008). The role of sensitizing experiences in music

performance anxiety in adolescent musicians. Psychology of Music, 36(4), 447-462.

Papageorgi, I., Creech, A., \& Welch, G. (2011). Perceived performance anxiety in advanced musicians specializing in different musical genres. Psychology of Music, 41(1), 18-41.

Papalia, D. E., Wendkos Olds, S., \& Duskin Feldman, R. (2003). Otrokov svet. Ljubljana: Educy.

Perak Lovričević, N. (2005). (Ed.). Glazbeno učilište Elly Bašic 1965-2005. Zagreb: GU Elly Bašić.

Pruett, K. (2003). First patrons: Parenting the musician, paper presented at 21 st Annual Symposium on the Medical Problems of Musicians and Dancers. Aspen, Colorado.

Renzulli, J. S. (1999). What is this thing called giftedness, and how do we develop it? A twenty-five year perspective. Journal for the Education of the Gifted, 23(1), 3-54.

Renzulli, J. S., \& Reis, S. M. (1997). The Schoolwide Enrichment Model: A how-to guide for educational excellence. Mansfield Center, CT: Creative Learning Press.

Rost, D. H., \& Schermer, F. J. (1986). Strategien der Prüfungsangstverarbeitung. Zeitschrift für Differentielle und Diagnostische Psychologie, 7(3), 127-139. 
Ryan, C. (1998). Exploring musical performance anxiety in children. Medical Problems of Performing Artists, 13, 83-88.

Ryan, C. A. (2003). A study of the differential responses of male and female children to musical performance anxiety. Dissertation Abstracts International Section, 63, 2487.

Ryan, C. (2004). Gender differences in children's experience of musical performance anxiety. Psychology of Music 32, 89-103.

Ryan, C. (2005). Experience of musical performance anxiety in elementary school children. International Journal of Stress Management, 12(4), 331-342.

Salmon, P. (1990). A psychological perspective on musical performance anxiety: a review of the literature. Medical Problems of Performing Artists, 5, 2-11.

Schlenker, B, R., \& Leary, M. R. (1982). Audiences' reactions to self-enhancing- self-denigrating, and accurate self-presentations. Journal of Experimental Social Psychology, 18, 89-104.

Simon, J. A., \& Martens, R. (1979). Children's anxiety in sport and non-sport evaluative activities. Journal of Sport Psychology, 1(2), 160-169.

Sternberg, R. J. (2003), Creative Thinking in the Classroom. Scandinavian Journal of Educational Research, 47(3), 325-339.

Studer, R., Danusera, B., Hildebrandt, H., Arial, M., \& Gomez, P. (2011). Hyperventilation complaints in music performance anxiety among classical music students. Journal of Psychosomatic Research, 70(6), 557-564.

Williams, D. (2012). Performance anxiety and the fight or flight syndrome. Journal of Literature and Art Studies, 2(5), 551-558.

Wilson, G. D. (2002). Psychology for performing artists: Butterflies and bouquets. London: Whurr.

Zarza-Alzugaray, F. J., Orejudo, S., Casanova, O., \& Aparicio-Moreno, L. (2018). Music

Performance Anxiety in adolescence and early adulthood: Its relation with the age of onset inmusical training. Psychology of Music, 46(1), 18-32.

Zatz, S., \& Chassin, L. (1985). Cognitions of test-anxious children under naturalistic test-taking conditions. Journal of Consulting and Clinical Psychology, 53(3), 393-401.

\section{Author}

\section{Blaženka Bačlija Susić, PhD}

Lecture, University of Zagreb, Faculty of Teacher Education, Savska 77, 10000 Zagreb Croatia, email: blazenkabs@gmail.com.

Predavateljica, Univerza v Zagrebu, Fakulteta za izobraževanje učiteljev, Savska 77, 10000 Zagreb Hrvaška, e-mail: blazenkabs@gmail.com. 